\title{
KONFLIK TOKOH UTAMA DALAM MENGHADAPI KETIDAKADILAN GENDER PADA NOVEL RE: KARYA MAMAN SUHERHMAN
}

\author{
Fajarika Ramadania ${ }^{1}$, Riduan Saberan ${ }^{2}$, dan Jamilah ${ }^{3}$ \\ ${ }^{1,2)}$ Pendidikan Bahasa dan Sastra Indonesia \\ STKIP PGRI Banjarmasin \\ Jalan Sultan Adam, Komplek H. Iyus, No. 18 RT.23 Banjarmasin, \\ Kalimantan Selatan. Kode pos 70121 \\ email: framadania@stkipbjm.ac.id \\ ${ }^{3)}$ UT Banjarmasin \\ Jalan Sultan Adam, Banjarmasin, Kalimantan Selatan
}

\begin{abstract}
Abstrak
Penelitian ini mengkaji tentang ketidakadilan gender dan konflik batin yang dialami oleh tokoh dalam novel. Tujuan penelitian ini adalah untuk: (1) Mendeskripsikan permasalahan mengenai ketidakadilan gender, (2) Mengemukakan konflik batin yang terjadi pada tokoh dalam, (3) Memaparkan pembentukan kepribadian tokoh dengan konflik yang terjadi disekitarnya.

Sesuai dengan konsep kajian dalam penelitian, maka pendekatan yang digunakan adalah pendekatan feminisme yang mencakup aspek-aspek feminisme yang terjadi dalam kehidupan dunia prostitusi. Metode yang digunakan dalam penelitian ini adalah metode deskriptif analisis. Sumber data yang digunakan dalam penelitian ini adalah novel yang berjudul $R e$ : karya Maman Suherman. Novel ini diterbitkan tahun 2014 oleh POP yang dicetak oleh Percetakan Gramedia. Teknik pengumpulan data yang digunakan dalam penelitian ini adalah teknik observasi teks dan teknik analisis data yang digunakan adalah deskriptif interpretatif.

Hasil dari kesimpulan penelitian ini adalah (1) ketidakadilan gender yang meliputi dalam kekuasaan dengan jumlah data sebanyak 11 pembahasan, pergaulan dengan jumlah 5 pembahasan, dan tingkah laku sebanyak 12 pembahasan, (2) konflik batin yang dialami oleh tokoh yang meliputi tentang dendam, marah, kecewa, sedih, takut dan bingung dengan jumlah total data sebanyak 38 pembahasan, (3) pembentukan kepribadian tokoh dengan konflik disekitarnya yang meliputi tentang faktor-faktor yang menyebabkan perubahan sikap dan hubungan antara sikap dan tingkah laku dengan data yang didapat sebanyak 4 pembahasan berisi tentang kisah Mamah Re: saat hamil, asal mula Re: mencari pelacur lesbian, kisah pelik kehidupan pelacur lesbian yang masih remaja bernama Nona, dan juga kisah sedih seorang lines bernama Windy. Masing-masing memiliki satu jumlah data.
\end{abstract}

Kata kunci: konflik, ketidakdilan, gender, kajian feminis.

\section{Pendahuluan}

Dalam kehidupan sehari-hari, manusia tidak pernah lepas dengan permasalahan dilingkungan sekitarnya. Berbagai permasalahan tersebut tidak selamanya stabil, ada kalanya menyimpang dan jauh dari aturan yang diterapkan oleh masyarakat dan seringkali menimbulkan sebuah konflik. Konflik permasalahan tersebut kadang bisa tergambar dari sebuah seni yang disebut dengan sastra. 
Sastra merupakan salah satu cabang kesenian yang selalu berada dalam peradaban manusia tidak dapat ditolak, bahkan kehadiran tersebut diterima sebagai salah satu realitas sosial budaya. Hingga saat ini sastra tidak saja dinilai sebagai sebuah karya seni yang memiliki budi, imajinasi, dan emosi, tetapi telah dianggap sebagai suatu karya kreatif yang dimanfaatkan sebagai konsumsi intelektual disamping konsumsi emosi.

Karya sastra imajinatif menjelaskan tentang fakta kehidupan juga realitas kehidupan. Sastrawan bersentuhan dengan realitas dan kemudian menafsirkannya, menjelaskannya, atau bereaksi. Sastra imajinatif lebih bertugas untuk menerangkan, menjelaskan, memahami, membuka pandangan baru, memberikan makna kepada realitas kehidupan.

Feminisme adalah gerakan atau paham yang dilakukan oleh perempuan dengan tujuan untuk memperjuangkan persamaan hak antara laki-laki dan perempuan sebagai kelas sosial. Hal ini sering mengacu pada penempatan perempuan sebagai pihak yang memiliki peran yang sama dengan lakilaki. Paham ini juga menekankan perempuan sebagai pihak yang bisa mendapatkan akses yang sama dalam segala aspek kehidupan, termasuk dalam dunia pendidikan, pekerjaan, politik, dan sebagainya.

Sejalan dengan proyek feminis yang bertujuan mengakhiri dominasi pria, kritik sastra feminis mengambil peran sebagai suatu bentuk kritik negosiasi, bukan sebagai bentuk konfrontasi. Kritik ini dilakukan dengan tujuan untuk menumbangkan wacana-wacana dominan, bukan untuk berkompromi dengan wacana dominan tersebut. Kritik sastra feminis lebih dari sekedar perspektif. Ia menampilkan kecanggihan dengan menggunakan aliansi strategi dengan teori-teori kritis (Ruthven, dalam Adib Sofia 2009: 21)

Sejak dulu perempuan menjadi makhluk yang tertindas karena adanya perbedaan gender yang sedemikian banyak sehingga sebagian besar masyarakat berpendapat bahwa perempuan hanya berperan sebagai makhluk yang memuaskan kenikmatan laki-laki. Padahal ada beberapa faktor yang mengharuskan seorang perempuan menjadi pelacur atau wanita tuna susila, salah satu faktor yang paling dominan karena adanya tuntutan ekonomi dan kebutuhan hidup yang semakin sulit. Kejamnya perlakuan para germo atau "mami" dalam lingkungan mereka membuat para perempuan ini bertahan dan tersiksa dalam lingkaran dunia prostitusi, kurangnya perlindungan untuk para PSK inilah yang menjadi topik utama dalam kajian feminisme.

Re: karya Maman Suherman merupakan novel yang menceritakan tentang kehidupan nyata seorang pelacur yang lebih tepatnya sering disebut sebagai pelacur lesbian. Dalam novel ini juga dihadirkan adanya seorang tokoh laki-laki yang bernama Herman yang juga berperan sebagai penulis novel. Ia merupakan salah satu mahasiswa kriminlogi yang meneliti tempat tinggal Re: dan kehidupan sekitar tempat tinggalnya sebagai objek penelitian skripsinya, namun yang terjadi malah 
sebaliknya.kisah hidup Re: yang berliku menyeret Herman hingga jatuh ke dalam. Herman terpaksa terlibat dalam sisi tergelap dunia pelacuran yang bersimbah darah, dendam, dan airmata.

Melalui novel inilah pengarang berhasil mengangkat cerita nyata tentang penindasan sesama kaum perempuan dalam dunia pelacuran dan konflik batin yang terjadi dalam kehidupan tokoh utama serta tokoh lain yang dituangkan kembali oleh si penulis. Berdasarkan latar belakang masalah di atas peneliti tertarik untuk mengadakan penelitian yang berjudul "Permasalahan Gender Dan Konflik Batin Yang Dialami Oleh Tokoh Dalam Novel Re Karya Maman Suherman”

\section{Metode}

Pada penelitian ini, peneliti menggunakan dua pendekatan yaituPendekatan Feminisme dan Psikologi. Pendekatan pertama yang digunakan adalah pendekatan feminisme. Yang mana artinya adalah pendekatan atau kajian yang membahas mengenai permasalahan hak-hak kaum perempuan sebagai kelas sosial. Di dalam pendekatan feminisme juga dijelaskan bagaimana permasalahan dalam ketidakadilan gender yang meliputi mengenai kekuasaan, pergaulan, dan tingkah laku manusia dalam kehidupan sehari-hari, konflikbatin yang dialamiolehperempuandanjuga tokoh lainnyadalamlingkungansosialdisekitar, serta bagaimana pembentukan kepribadian tokoh dengan konflik yang terjadi dalam hidupnya. Sedangkan pendekatan yang kedua menggunakan pendekatan kajian psikologi. Pendekatan psikologi adalah pendekatan atau kajian yang membahas tentang unsur kejiwaan pengarang atau tokoh yang termuat dalam karya sastra, baik dalam cerpen, novel, maupun puisi (Minderop, 2016:53).

Jenis penelitian ini adalah penelitian kepustakaan (library research).Disebut penelitian kepustakaan karena data-data atau bahan-bahan yang diperlukan dalam menyelesaikan penelitian tersebut berasal dari perpustakaan baik berupa buku, ensklopedi, kamus, jurnal, dokumen, majalah dan lain sebagainya (Harahap, 2014:01).

Metode yang digunakan dalam penelitian ini adalah deskriptif analisis. Metode deskriptif analisis dilakukan dengan cara mendeskripsikan fakta-fakta yang kemudian disusul dengan analisis (Ratna, 2013: 53).

Sumber data dalam penelitian ini adalah novel Re: karya Maman Suherman. Novel ini diterbitkan oleh Percetakan Gramedia, Jakarta tahun 2014 dengan tebal 160 halaman. Adapun dalam novel tersebut terdapat 14 bagian cerita, dan 1 catatan dari si penulis. Teknik pengumpulan data yang digunakan dalam penelitian ini adalah teknik observasi teks dan teknik dokumentasi, yaitu mengumpulkan data-data yang diambil dalam novel $R e$ : yang dikarang oleh mantan mahasiswa kriminolog bernama Maman Suherman. 
Langkah-langkah kerja pengumpulan data dalam penelitian ini adalah sebagai berikut:

a. Pembacaan novel yang berjudul Re: karya Maman Suherman dari awal hingga akhir secara berulang-ulang untuk memperoleh gambaran isi cerita dalam novel tersebut.

b. Mencatat setiap kutipan novel yang berjudul Re: karya Maman Suherman yang sesuai dengan permasalahan yang diangkat berupa kalimat atau satu paragraf atau aline yang utuh.

c. Mengidentifikasi dengan mengadakan pemilihan dan pemilahan bagian-bagian dari data yang dianalisis. Tahap ini bertujuan untuk mengambil data yang diperlukan saja sesuai dengan permasalahan peneliti.

Dalam melakukan sebuah penelitian diperlukan adanya suatu instrumen. Instrumen penelitian adalah alat yang merujuk pada sarana pengumpulan data (Siswantoto, 2005:65) dalam (Kartikasari, 2014: 36). Instrumen dalam penelitian ini menggunakan tabel kisi-kisi penjaringan data yang diberi nomor, data, kode data, deskripsi, dan interpretasi pada kutipan-kutipan teks yang dibutuhkan. Penggunaan tabel tersebut akan memudahkan peneliti untuk mengolah, menganalisis, dan menginterpretasi data yang telah didapatkan. Intrumen penelitian ini merupakan alat bantu yang digunakan penelitian untuk mengumpulkan data. Instrumen penelitian ini diharapkan mampu memberi bantuan agar proses penelitian menjadi lebih terarah pada pencapaian tujuan penelitian.

Setelah data terkumpul kegiatan selanjutnya adalah melakukan analisis data, maka teknik yang digunakan dalam analisis data yaitu langkah-langkah yang berdasarkan dari metode penelitian yang telah ditetapkan dengan cara mendeskripsikan fakta-fakta yang kemudian disusul dengan analisis. Untuk menganalisis data dilakukan tahap sebagai berikut:

a. Menganalisis

b. Mendeskripsikan hasil analisis dengan maksud untuk menemukan unsur-unsurnya.

Prosedur penelitian atau tahap kerja penelitian ini dibagi menjadi: 1) Tahap persiapan, yaitu pemilihan serta pemantapan judul penelitian dan menyusun rancangan penelitian. 2) Tahap pelaksanaan yaitu mengumpulkan data, pengolahan data, penafsiran hasil pengolahan, dan membuat kesimpulan hasil penelitian. 3) Tahap penyelesaian, yaitu penulisan laporan penelitian, revisi laporan penelitian, dan pengadaan laporan penelitian serta penyerahan ke lembaga.

\section{Hasil dan Pembahasan}

Berdasarkan hasil penelitian, pembahasan mengenai ketidakadilan gender dan konflik batin dalam novel $R e$ : akan dikemukakan dalam tiga aspek pembahasan penelitian yang meliputi ketidakdilan gender, konflik batin, dan pembentukan kepribadian tokoh denggan konflik di sekitarnya. 


\section{Ketidakadilan gender}

Berdasarkan hasil penelitian, pembahasan mengenai ketidakadilan gender yang terjadi dalam novel Re: dapat dibagi dalam tiga sub variabelmengenai ketidakdilan dalam kekuasaan, pergaulan dan tingkah laku. Adapun perolehan gambaran data yang terbanyak didapat dari hal tingkah laku tokoh dengan frekuensi kemunculan sebanyak 12 pembahasan, selanjutnya adalah gambaran mengenai ketidakadilan kekuasaan sebanyak 11 pembahasan dan gambaran mengenai pergaulan sebanyak 5 pembahasan. Terdapat masing-masing satu jenis fenomena pada gambaran kekuasaan, pergaulan, dan tingkah laku manusia.

\section{Konflik Batin}

Konflik batin yang dialami oleh tokoh dalam novel Re: dapat diketahui dari beberapa macam, diantaranya, Dendam adalah perasaan keinginan yang bertujuan untuk membalas perbuatan atau kejahatan sesorang. Wujud konflik batin jenis dendam yang ditemukan dalam pribadi si tokoh Rere. Marah adalah perasaan tak senang atau benci terhadap suatu sikap atau sifat sesorang. Wujud konflik batin berjenis marah yang ditemukan dalam pribadi si tokoh Rere, Mami Lani, dan Windy. Kecewa adalah perasaan tidak merasa puas terhadap harapan, keinginan, atau dugaan, gagal dalam usaha dan sebagainya. Wujud dari konflik batin jenis kecewa yang ditemukan dalam novel Re: banyak digambarkan pada tokoh Rere. Sedih adalah perasaan susah hati, merasa sangat pilu dalam hati, dan menimbulkan rasa susah. Wujud dari konflik batin jenis sedih dalam novel Re: bisa digambarkan dalam ungkapan tokoh Rere dan Ibunya. Takut adalah perasaan yang merasa tak berani, ngeri, gentar saat melihat sesuatu yang merasa mendatangkan bencana atau kesusahan pada dirinya. Wujud dari konflik batin jenis takut dalam novel Re: dapat ditemukan dalam ungkapan Nini, Rere, dan juga si tokoh Dika. Bingung merupakan perasaan yang merasa tidak tahu arah dan tujuan yang pasti. Atau perasaan yang menitikberatkan pada ketidaktahuan dalam memutuskan atau mengambil suatu tindakan. Wujud dari konflik batin jenis bingung dalam novel Re: dapat ditemukan pada gambaran yang diungkapkan, Mak Siti, dan juga Rere.

\section{Pembentukan Kepribadian Tokoh dengan Konflik Disekitarnya.}

Dalam hal ini, kepribadian tokoh yang terbentuk berhubungan erat yang konflik yang terjadi di sekitarnya, karena dalam menghadapi setiap masalah, secara perlahan-lahan kepribadian atau watak dari seorang manusia akan terbentuk. Meski melalui konflik yang cukup menengangkan dan menguras emosi. Serta kesedihan yang cukup mendalam.

Berdasarkan hasil penelitian, pembentukan kepribadian tokoh dengan konflik di sekitar dapat digambarkan dalam dua unsur yaitu penyebab perubahan sikap. Setiap manusia, sikap atau sifatnya bisa berubah tergantung dari faktor yang mempengaruhinya, faktor tersebut bisa berasal dari dalam 
diri pribadi atau yang bisa disebut dengan faktor intern, sedangkan faktor yang kedua bisa juga berasal dari luar pribadi orang itu sendiri dengan nama lain disebut juga sebagai faktor ekstern (Abu Ahmadi, 2007:159). Kemudian unsur yang kedua meliputi adanya hubungan yang erat antara sikap dan tingkah laku, semua ini didukung juga oleh pengertian sikap yang menyatakan bahwa sikap merupakan kecendrungan untuk bertindak (Abu Ahmadi, 2007:159). Berkenaan dengan hal ini maka, ditemukan ada beberapa hubungan antara konflik dengan pembentukan kepribadian tokoh yang terjadi pada tokoh Mamah Re saat hamil, asal mula Re menjadi pelacur lesbian, kisah pelik kehidupan pelacur lesbian yang masih remaja bernama Nona, dan juga kisah sedih dari seorang lines bernama Windy.

\section{Simpulan}

Dalam novel $R e$ : terdapat pesan-pesan moral yang dapat dijadikan pelajaran bagi pembaca. Pesan moral yang dapat diperoleh dari cerita yang terdapat dalam novel tersebut adalah sebagai berikut:

1. Mengenai ketidakdilan gender merupakan pesan yang ingin disampaikan pengarang sebagai bentuk pertentangan yang dilakukan oleh para tokoh perempuan. Pengarang mengharapkan adanya keselarasan antara perempuan dan laki-laki dalam pergaulan. Dalam novel $R e$ : terdapat beberapa pesan ketidakadilan gender yang meliputi: (a) keserataan gender dalam hal kekuasaan, dalam novel ini dijelaskan mengenai adanya ketidakadilan gender yang dilakukan oleh sesama perempuan maupun oleh laki-laki yang masih sering terjadi dalam kehidupan sehari-hari, terlebih dalam dunia prostitusi yang seringkali dianggap dunia gemerlap oleh sebagian orang padahal sebenarnya banyak tindak kekerasan yang sering diterima oleh para pekerjanya (b) Pergaulan, dalam novel $R e$ : terdapat beberapa jenis pergaulan yang menyimpang dari lingkungan dunia prostitusi, mereka banyak mengalami kelainan atau perbedaan dalam hubungan sosial baik sesama perempuan ataupun dengan lawan jenisnya (c) tingkah laku manusia, dalam novel ini juga dijelaskan tentang bagaimana adanya ketimpangan dalam tingkah laku, khususnya yang terjadi pada kaum perempuan, ketimpangan dalam tingkah laku terjadi karena adanya perbedaan dalam hal kekuasaan, konflik batin yang bergejolak dalam diri individu karena adanya kesalahan di masa lalu, maupun gender.

2. Pesan pergolakan batin yang terjadi pada tokoh. Dalam novel $R e$ : pesan pergolakan batin yang terjadi meliputi: (a) sedih, dalam novel ini terdapat banyak sekali konflik tentang kesedihan yang sering dialami oleh si tokoh Bulat, Re selain itu hal ini juga dialami oleh mamahnya Re (b) marah, dalam novel ini juga terdapat banyak konflik tentang amarah yang juga banyak dirasakan oleh si tokoh bulat maupun tokoh sederhana (c) konflik batin jenis takut juga banyak dialami oleh beberapa tokoh perempuan saat terjadi beberapa permasalahan dalam menjalani 
pekerjaan sehari-harinya sebagai wanita tunasusila (d) tentang kebingungan juga menjadi pergolakan batin yang terjadi dalam tokoh berkembang maupun tokoh statis (e) konflik batin jenis dendam juga tak luput dialami oleh tokoh Re (f) tentang kekecewaan juga dirasakan oleh si tokoh utama.

3. Mengenai perubahan sikap dan tingkah laku yang dialami oleh tokoh perempuan karena pengaruh konflik disekitar. Mengenai perubahan sikap dan tingkah laku dalam novel Re:, meliputi: (a) kisah tentang Mamah Re yang tiba-tiba hamil (b) bagaimana peristiwa yang melatarbelakangi Re menjadi pelacur lesbian (c) bagaimana kisah seorang remaja yang masih SMA bernama Nona menjadi bagian dalam dunia prostitusi dan juga (d) bagaimana kisah seorang Windy menjadi lesbian.

\section{Saran}

Pada bagian akhir skripsi ini, peneliti ingin menyampaikan saran dan selanjutnya diharapkan dapat menjadi masukan yang bermanfaat bagi pihak-pihak yang berkepentingan sehubungan dengan penelitian yang dilakukan berkenaan dengan objek yang diteliti. Novel merupakan salah satu gambaran kehidupan masyarakat yang disampaikan pengarang baik yang bersifat nyata maupun fiksi dengan tujuan untuk menghibur dan memberikan pesan edukasi. Pada novel $R e$ : saran yang ingin disampaikan sebagai berikut:

1. Bagi pembaca, diharapkan bisa menyaring pesan edukasi yang ada pada novel tersebut dan mampu mengambil hikmah ataupun manfaat dari cerita yang ada dalam novel.

2. Novel $R e$ : terdapat banyak pesan moral dibalik gemerlapnya dunia prostitusi yang jarang terlihat oleh dunia luar bahwa sering terjadi penyiksaan terhadap kaum perempuan.

3. Hasil penelitian ini dapat menambah referensi penelitian karya sastra dan dapat dijadikan sebagai acuan bagi mahasiswa STKIP PGRI Banjarmasin yang ingin meneliti tentang permasalahan mengenai perempuan ditahun berikutnya.

\section{Daftar Pustaka}

Ahmadi, Abu. 2007. Psikologi Sosial. Jakarta: PT. RINEKA CIPTA.

Departeman Pendidikan Nasional. Kamus Besar Bahasa Indonesia. 2013. Jakarta: PT. Gramedia Pustaka Utama.

Minderop, Albert. 2016. Psikologi Sastra. Karya Sastra Metode, Teori, danContoh Kasus. Jakarta: Yayasan Pustaka Obor Indonesia.

Nurgiyantoro, Burhan. 2015. Teori Pengkajian Fiksi. Yogyakarta: Gadjah Mada University.

Pisani, Elizabeth. 2008. Kearifan Pelacur (Kisah Gelap di Balik Bisnis Seks dan Narkoba. Jakarta: Serambi Ilmu Semesta. 
Ratna, Nyoman Kutha. 2013. Teori, Metode, dan Teknik Penelitian Sastra. Yogyakarta: Pustaka Pelajar.

Sofia, Abid. 2009. Aplikasi Kritik Sastra Feminisme Perempuan Dalam Karya-karya Kuntowijoyo. Yogyakarta: Citra Pustaka.

Sugihastuti. 2009. Rona Bahasa dan Sastra Indonesia. Yogyakarta: Pustaka Pelajar Offset.

Suherman, Maman. 2014. Re:. Jakarta: Percetakan Gramedia.

Syuropati, Muhammad A dan Agustina Soebachman. 2012. 7 Teori Sastra Kontemporer \& 17 Tokohnya. Yogyakarta: IN AzNa Books.

Wahyuningtyas. Sri danWijayaHeruSantosa.2011. Sastra: TeoridanImplementasi. Surakarta: Yuma Pressindo.

Wiyatmi, 2012. Kritik Sastra Feminis Teori dan Aplikasinya dalam Sastra Indonesia. Yogyakarta: Penerbit Ombak.

WS, Indrawan. 2014. Kamus Lengkap Bahasa Indonesia. Jombang: Lintas Media. 